\title{
Evaluating the Palestinian Woman's Image in the Local Media from the University Female Students' Perspective in Gaza
}

\author{
Fatheya S. Alloolo \\ Department of Methodology and Curriculum, \\ Islamic University of Gaza (IUG), Gaza Strip, Palestine \\ Tel: 970-59-7303105. Fax: 870-8-2644800. E-mail: floolo@iugaza.edu.ps \\ Roba A. Abu Kmeil \\ Department of Methodology and Curriculum, \\ Islamic University of Gaza (IUG), Gaza Strip, Palestine
}

Received: May 24, 2016 Accepted: May 26, 2016 Published: May 26, 2016

doi:10.5296/jpmr.v2i1.9517ＵRL: http://dx.doi.org/10.5296/jpmr.v2i1.9517

\begin{abstract}
Descriptive approach via a questionnaire to evaluate the Palestinian woman's image in media at different levels in Gaza strip, Palestine. 530 female university students were drawn from three universities in Gaza strip involving the Islamic university, Al-Azhar university, and university of Palestine. The outcomes of this study show that women have two prominent traits in that media that is self-made and patient, and sacrificing. The other traits include weak and needy. In addition, at the political level, the media has demonstrated interests in the Palestinian media ladies, and shown their roles in covering the Palestinian political news. At the social level, the outcomes have proved that social media networks have contributed in shaping the mainstream supporting the Palestinian woman's social issues. Besides, at the cultural level, they have stated that customs and traditions hinder media from adopting courageous issues treating the Palestinian woman's political and social status quo. Furthermore, at the economic level, media has given an image about the working Palestinian woman's materialistic abuse. In conclusion, the media should not exaggerate in portraying the woman's image in the issues of violence. It is necessary to present a positive image about her and defend her freedom and rights. Moreover, it recommended to support her to be designated in governmental, ministerial and leadership positions, as well as, to cast light on
\end{abstract}


exemplars for successful women in the field of reasoning and knowledge, and set a media plan based on justice and equality.

Keywords: Woman; media; woman's image; social; political; cultural; economic; Gaza; Palestine

\section{Introduction}

Women comprise almost half of the population of any society. They have contributed in the development of human civilization. This implies that women play effective roles in the political, social, economic, technological and scientific fields. In particular, the Palestinian women are considered great exemplars in all domains since they combined the distinct attributes of the old women and the modern women. They work hard for upholding their specific identity, which is a reflection of the genuine Palestinian culture. This obviously shows they have exerted great undeniable efforts in their positions (Abu-Taha, 2013).

Media is an important tool which contributes in spreading awareness across society about women's rights and responsibilities and the roles of the society in disseminating and turning awareness into effective policies, values and behaviors that can transform the defacto woman's negative status quo into mechanisms helping promote the society thoroughly (Kamel, 2006). Media has massive potential and can improve woman's circumstances in case this potential is employed properly. Moreover, media is like a mirror conveying the small and big particulars into the mind of the watcher, reader and listener through different channels with different objectives. Specifically, electronic media, which helps spread what's happening all over the world in a twinkling of an eye and make individuals in a direct touch with what's going on around them, has rapidly spread (Hazayma, 2006). In this regard, many electronic websites have been precisely established for raising women's voice like AVIVA, which is an international net run by a global woman team in London. In Asia, there is another net of information operating to disseminate awareness for empowering women (give examples of such websites from Asia and their specific role (Ramzy, 2001).

Contrary to the traditional media, the social media websites have global impact specifically the display of positive image of women. However, it is important that there must be some criteria shaping the women's positive image, especially the Palestinian woman.

\subsection{Definition of woman's image in media}

Shimon (2010) and An-Nahr et al. (2008) define woman's image as everything about woman's existence, her activities, what hinders her efforts or helps her and what helps understand her problems, requirements, and humanitarian needs. The Arab Cultural Center for Studies defines it as the image or the issues that arise out of stances with contradictory descriptions of the social, humanitarian, interactive roles (Shimon, 2010). Moreover, Bader \& Al-Mousa (2009) define it as the impressions that have been constituted about women and their traits through media. Besides, Yusuf (2005) defines it as the traits and the impressions 
that media forms about women through the conceptualization of an elite of intellectuals through media.

The researchers of this study define it as the mental impressions formed out of what media reflects about women's issues, achievements and circumstances. It also represents all the positive and negative allusions of what is presented in media.

\subsection{Efforts exerted for improving the image of women}

Many of efforts have been exerted for improving the image of women. In 1975, the United Nations held the first international conference which concluded that the relationship between media and women is of great importance. That's because contacting is an effective power granting women the ability to effectively contribute in making decisions, affecting the public policies and changing the thoughts and beliefs about women (Shimon, 2008). The efforts of the United Nations continued to improve the image of women. This has been represented in hammering an agreement in 1979 for ending discrimination between the two genders (Kamel, 2006).

In eighties, two conferences were held. The first one was Copenhagen in 1980 which came as a declaration for terminating the act of discrimination between man and woman and among women themselves in terms of race, religion, social and economic status. The Second one was in Nairobi in 1985 which is a positive step for shaping strategies helping reinforce equality between men and women and bridging the gender gap. Moreover, the United Nations held one of the most important conferences in 1995 in which 189 countries participated and some other Non-Governmental Organizations. It discussed all woman issues known as woman rights as a part of human rights (Al-Manshi, 2011).

On the other hand, in 1995 the proclamation of Beijing has underscored the importance of empowering women to be decision makers in the field of media and communications in order to confront the commonplace stereotype about women. It has also stated that it's important to address some issues as the lack of woman's existence in the position of making decisions in media. Another issue it has also tackled is that those who work in media are not equipped enough with knowledge about gender and its importance. The scant number of networks of lady journalists working to support each other (Shimon, 2010).

Furthermore, in the kingdom of Bahrain in 13-15 November of 2006, the first conference of the Arab Woman's Organization was held in which the workshop of woman and media. Arab Woman's Organization (2008) mentioned some of these recommendations as:

- Offering an annual national award to the works of media that reinforce the image of Arab women and her historical and contemporary contributions.

- Classifying the woman and media issues as national ones to be periodically discussed in the Arab communities to boost the social and cultural awareness about this issue. That's due to the claim that media has its important and dangerous social and cultural consequences in the short and long terms. 
- Enacting woman regulations and rules to encourage participation at the public and media levels in particular.

- Making important changes by media organizations in its work, professional values and its criteria of recruitment, bearing in mind presenting a balanced and humane image of women. This can’t be achieved without adopting ethical and professional obligations preventing the act of offending women.

- Coordinating effectively between media organizations and educational ones in the Arab communities.

In Palestine, a great benefit has been attained out of all the conferences that have been held for improving the image of women, which makes the role of media in a need to double efforts for the same goal.

\subsection{Role of Feminist Organizations and Community Organizations in Improving the Woman's Image in Media}

The feminist organizations and the community organizations play a great role in improving the image of women in media. In this regard, the researchers of this study agree with Shimon (2010) on the roles both of the feminist organizations and the civil community organizations have to perform to improve the image of women. They include:

- Demonstrating interest in media field, improving the performance of media, training the employees and increasing the international writings for improving the image of women.

- Establishing a media observer for monitoring the woman's image presented in media, discovering the cases of distorting the image of women, and then taking executive measures for ending this cases.

- Increasing the number of programs talking about woman issues, covering all interests, and setting woman issues as of media priorities.

- Transmitting the production of the feminist organizations to the various categories, miscellaneous levels of men and women.

- Creating complementary techniques of performance and intervention for having the long-term goals achieved for reinforcing the positive and various woman images.

- Demonstrating interest in the media content presented and the range of continuity of presenting the media messages connected to the objectives of bolstering women socially, economically, and medically.

- Inviting written, audio and visual media for formulating a media policy including plans and well-prepared programs maintaining balance in presenting the roles, achievements and the social and cultural responsibilities for men and women for formulating a societal vision for the woman roles her societal responsibilities. 
- Having media connect between the policies of empowering women and the issues of the societal

In addition, the researchers of this study agree with Al-Zubedi (2005) on the roles of the feminist organizations helping improve the image of women. They include:

- Intensifying the printed periodicals like newspapers, magazines and distributing them in the marginalized areas.

- Navigating through the internet and employing this commonly-used method for the advantage of women.

- Developing an Arab Palestinian list of the media terms related to women like (Al-gender) to go in harmony with the culture and the understanding of the countryperson.

- Encouraging the media initiative covering the woman issues and presenting positive aspects about her through pictures, news, essays, or investigation. Offering financial and non-financial gifts for this purpose and holding annual celebrations are important too.

- Presenting women in their model roles in the Palestinian society as journalists, lawyers, poetesses, writers, minsters, managers...etc.

In addition, Ramzy (2001) adds some factors helping improve the image of women in media as:

- Considering the woman's issues as an integral part of the issues of the society, and avoiding the inequitable segregation leading to the divisive vision towards women and ignoring her real role.

- Bridging the gap between woman and man and reconsidering the communicative material causing the gender discrimination between both genders, which indicates to the notion that women have been created for housekeeping and giving birth, while men have been created for work and production.

- Ending the gap between what is presented about women in media and their defacto states and what they have achieved in different areas.

- Demonstrating interest for human beings through the communicative process and training those who work in the field of media in order to qualify the technical cadres more and creating new cadres. That will help deal with the media and cultural materials presented more effectively. Besides, the media materials must be purified from the attempts aiming to deepening the gender differences and the superiority of men to women.

- Empowering women and helping designate them in positions of making decisions, expressing themselves, making important decisions in media, and training them well how to use the modern technology of communication. 


\section{Literature Review}

Amid the international interest in woman's issues and her active participation in the formulation of new patterns of life in the communities, and the great role that media played to shape the woman's image in the communities and its participation in covering women's news; the research interest in the study of woman and female press has increased and adopted by research institutions, universities and organizations. Among of these studies, Albayadi \& Somaisem (2013) aimed at knowing the role of media in empowering the rights of the Palestinian refugee woman from the point of views of media female college students in Gaza strip. The study followed the descriptive analytical approach, and used a form distributed over 175 female students. The results have revealed that the role of the Palestinian media was dissimilar towards the rights of the refugee woman; sometimes it gives her interest, another it doesn't.

In the context, Abu-Taha (2013) conducted a study aimed at identifying the impact of using the social media networks on raising the social issues of woman form the Palestinian journalists' point of view in Gaza Strip. It followed the descriptive analytical approach and used a form distributed over 50 journalists of both genders. The study also depended on the focus groups with 50 male and 50 female journalists. The study has found that the level of interaction with women's issues and the views of the social organizations to women's issues are under estimations as there exist obstacles standing in front of discussing women's issues; most important of these obstacles are the customs and traditions of the society.

Whereas Ghattas \& Sawadeh (2011) aimed at analyzing the content and attitudes of the daily press on the coverage of the woman's image, and knowing the way through which this press introduces the Palestinian woman's issues. The study followed the descriptive analytical approach and used an analyzing tool to analyze the study sample composed of 86 newspapers of the Palestinian daily newspapers which are: Al-Quds, Al-Ayyam, Al-Hayyat, and Al-Jadida. Monitoring these three newspapers has shown the Palestinian woman's marginalizing and the unfair appearance and less heading of events in these newspapers.

On the other hand, Shimon (2010) aimed at determining the types of interventions and policies locally required to treat the stereotyped image of women in the mass media, audible, visible and printed, which have influence on the Gaza Strip society. It also aimed at revealing the Gazan woman's true image and determining the bodies capable to make this change. The study depended on the comprehensive interviews and it has revealed that the current image is presented in a stereotyped manner in which the suffering advances the achievement and the woman is introduced as subject to man instead of highlighting her independent character.

Additionally, Al-Dahdouh (2010) conducted a study to recognize the female students' opinions about the woman's image presented in the satellite advertisements. The researcher adopted the descriptive approach and conducted a survey to poll a sample of 113 female students from the Islamic University of Gaza. The results showed that the satellite channels had a significant role in distorting women's image, and that women were exploited through advertisements, some related, and others unrelated to them. Moreover, advertisements aimed at highlighting a woman's beauty more than the advertised item. 
Also, Bader \& Al-Mousa (2009) also aimed to observe the image of the Jordanian women in the Jordanian press. The study followed the descriptive and analytical approach, and used a tool represented in 42 issues of three daily newspapers (Alrai, Aldostour, Alghad) in 2007 in order to analyze the sample. The results showed that the image of the women wasn't balanced; there was, rather, a bias in favor of women in urban areas and neglect of women in rural ones.

Furthermore, An-Nahr et al. (2008) aimed at studying the image of women in the Arab media analytically, and took MBC-1 channel as a model. The researcher developed a model to analyze the content of women's image. MBC-1 channel showed the image of women positively and negatively through its various programs (drama-commercials- culture- news) among others. The researcher found that the change of women's image depended mainly on women's consistent struggle.

Moreover, Kamel (2006) conducted a study to observe, analyze, and critique the content presented in the Egyptian and Bahraini media about women. The study included the press, the $\mathrm{TV}$ and the radio to look into the extent of their consideration for the concept of gender equality. The study relied on the media survey approach, both the analytical and field. The study also relied on two tools: the content analysis and the survey, which were applied on a set of Egyptian and Bahraini media outlets. Moreover, the sample included 600 women divided in half between Egypt and Bahrain. The results showed that the Egyptian and Bahraini women still suffer from problems connected to their social and legal issues, with the violence against women being in the forefront.

As well, Yusuf (2005) aimed to observe the image that the religious press reflected of Muslim women, and investigated how much of attention the religious press gave to their issues. The study followed the comprehensive survey approach, and used the content analysis tool to analyze the sample that consisted of 116 issues distributed between these three magazines: Al-liwaa Al-Islami, Aqedati, and Alzhar. The results revealed that the religious magazines gave little attention to the legal field which is related to family law, and that it didn't care about the political issues connected to women. Also, the image of the women who are conscious of their political and legal rights wasn't explicit in the religious magazines.

In addition, Al-Damiri (2002) aimed at analyzing the women's status quo in the Jordanian journalism. The study relied on the analytical approach and applied a tool of analysis for analyzing the sample of the study that is of the four daily Jordanian newspapers from February 9, 2002 to February 15, 2002. They are Al-Aswaq, Al-Arab, Al-Yawm and Al-Raey. The results of the study showed that the Jordanian journalism allocates $5.14 \%$ out of its total topics for women. It also showed that men's contributions of writing about women surpass the ones produced by women.

Finally, Al-Salem (1997) conducted a study for analyzing the image of the Arab woman in the televised drama. The researcher followed the analytical approach. She implemented a tool of analysis for analyzing a random sample of what's presented through the Jordanian TV from November 1, 1992 to February 31, 1994 out of social Arab drama on the First Channel. The analysis of woman's image showed that she is subjugated and that her utmost interest is how to keep her beauty and appearance. It also showed that a woman is also patient and 
pathetic with no independent entity and she feels her identity through man as a father, husband and brother.

\subsection{Commentary on the Previous Studies}

Through the previous studies, we notice that most of them observed the woman's image in the various forms of media, like the social media, newspapers and televisions. The studies followed different approaches like the descriptive approach and the analytical approach. The tools they applied were also miscellaneous. They included questionnaires, tools of analysis, interviews and investigations. Eventually, most of the results showed that the woman's appearance on media is not fair and that the coverage and the expression of women's image are considerably ignored.

\section{Problem Statement}

Since media is an integral part of the contemporary life and plays a significant role in shaping people's attitudes and beliefs about women, there must be clear criteria for the Palestinian woman's image that media can depend on when addressing women's issues. That's because media's addressing of women's issues is a double-edged weapon by which both of the positive and negative images can be formed. Thus, this study has come to finally recognize the Palestinian woman's image in the local media from the Palestinian university female students' perspective.

\subsection{The problem of the study is confined to the following major question}

What are the evaluative estimations for the Palestinian woman's image in media from the Palestinian university female students' perspective?

\subsection{The following minor questions extend out of the previous major one}

1. What is the Palestinian woman's trait like in media from the university female students' perspective?

2. What is the Palestinian woman's general image like in media from the Palestinian university female students' perspective in Gaza?

3. What is the Palestinian woman's image like at the social level in media from the Palestinian university female students' perspective in Gaza?

4. What is the Palestinian woman's image like at the political level in media from the Palestinian university female students' perspective in Gaza?

5. What is the Palestinian woman's image like at the cultural level in media from the Palestinian university female students' perspective in Gaza?

6. What is the Palestinian woman's image like at the economic level in media from the Palestinian university female students' perspective in Gaza?

\section{Objective}




\section{Macrothink}

The study has sought to recognize the Palestinian woman's image in the local media from the university female students' perspective in Gaza.

\section{Significance of the Study}

It provides a questionnaire for recognizing the Palestinian woman's image in media's social, political, cultural, economic fields. It can enable other media persons, especially the Palestinian media person, to help improve the woman's image and make it more positive and interactive.

\section{Terminology}

Woman's Image: It is the mental impressions resulting out of what media reflects about the woman's issues, achievements, behaviors, roles and states. Moreover, it represents all the positive and negative allusions of what is presented in all media.

Media: The official and unofficial methods and techniques that disseminate information, data, news, facts in all different fields.

\section{Methods and Materials}

\subsection{Approach of the Study}

The researchers of this study of this study followed the descriptive approach whereby they collected data about the woman's image in media. They set a questionnaire for identifying the Palestinian woman's image in media from the Palestinian university female students' perspective in Gaza.

\subsection{Sampling}

530 female students of the Islamic University of Gaza, Al-Azhar University, and University of Palestine who are enrolled in the first semester of the academic year of 2015-2016. Table 1 describes the distribution of the Individuals of the study on the Variables of the Study.

Table 1. Distribution of the study participants based on the change of level and university of enrollment

\begin{tabular}{cccc}
\hline & & No. & $\%$ \\
\hline \multirow{3}{*}{ University } & Islamic University & 264 & 49.8 \\
& Al-Azhar University & 158 & 29.8 \\
& University of Palestine & 108 & 20.4 \\
& First & 135 & 25.5 \\
Level & Second & 127 & 24 \\
& Third & 155 & 29.2 \\
& Fourth & 113 & 21.3 \\
\hline
\end{tabular}




\subsection{Study Tools}

The tool of the study is a questionnaire for recognizing the Palestinian woman's image in the Palestinian media. Accordingly, the tool of the study has been prepared in accordance with the following steps:

1. Reviewing the previous studies related to the subject matter of this study.

2. Setting a questionnaire of items for recognizing the Palestinian woman's image in the Palestinian media. The questionnaire is of 26 items distributed among four domains. The domain of the Palestinian woman's image at the social level includes 7 items, the domain of the Palestinian woman's image at the political level includes 6 items, the domain of the Palestinian woman's image at the cultural level includes 8 items, and eventually, the domain of the Palestinian woman's image at the economic level includes 5 items. In Addition, a quadric scale has been applied for the items (Yes, Sometimes, I don't know, No), and the following weights $(1,2,3,4)$ have been given. Therefore, the individuals' degrees of the study sample have been confined to (26_104). The questionnaire has been executed on the Palestinian universities' female students. Besides, the statistical treatments and the outcomes have been successfully processed.

\subsection{Validity of the tool}

3. The Panelists' validity: To verify the validity of the tool, it has been submitted to a committee of five specialized panelists from Palestinian universities. Their recommendations on modifying, deleting, adding and reformulating have been followed by $80 \%$.

4. Content validity: The content validity has been ascertained by applying the scale on a pilot sample of 40 female students selected randomly. Moreover, the Pearson Correlation Coefficient has been calculated between each item of the scale and the total degree of the scale for finding the strength of the correlation between the degrees of every item and the domain to which it belongs and the correlation degree of every domain with the total degree of scale. It has been found that the values of the correlation coefficient are between (0.350-0.899), and they are all statistically indicative at 0.05 .

\subsection{Reliability of the questionnaire}

Cronbach's Alpha has been calculated for estimating the reliability of the questionnaire on the individuals of the pilot sample. First, the social domain is 0.829 , the political domain is 0.638 , third, the cultural domain is 0.813 , the economic domain is 0.767 , and the questionnaire in general is 0.834 . As a result, this indicates that the scale is of a high degree of reliability.

\section{Outcomes of the Study}

8.1 The answer of the first question of study 
Table 2 represents the question, which is "what is the Palestinian woman's image like in media from the university female students' perspective?”. The choices of this item include (leader, housewife, self-made, patient, weak, needy, partner of man, sacrificing, educated, or other). This trait is entirely logical due to the exceptional circumstances of Palestinians live. The frequent wars position her as a self-made and patient woman at the first rank since she has been sacrificing the invaluable thing, her sons. However, she is leader and educated as well, but she is not weak or needy.

Table 2. The Palestinian Woman's traits

\begin{tabular}{lccc}
\hline \multirow{2}{*}{ Question } & Trait & No. & $\%$ \\
\hline & Very weak & 15 & 2.8 \\
& Man's Partner & 30 & 5.7 \\
How does media present the & Other & 3 & 0.6 \\
Palestinian Woman's image? & Educated & 39 & 7.4 \\
& leader & 51 & 9.6 \\
& housewife & 123 & 23.2 \\
& Sacrificing Mother & 132 & 24.9 \\
& Patient and self-made & 137 & 25.8 \\
& & 530 & 100 \\
\hline
\end{tabular}

\subsection{The answer of the second question of the study}

Table 3 represents the question, which is "what is the Palestinian woman's image like in media from the Palestinian university female students' perspective in Gaza?”. The arithmetic means and standard deviations of the individuals' responses of the study sample have been calculated. The Global Gradient has been followed for analyzing the outcomes. It has classified ratios as follows: (90-100) are excellent, (80-90) are very good, (70-80) are good, (60-70) are fair, and (0-50) are weak.

It's clear that the woman's image at the political level is in the first rank with a relative weight of $71.75 \%$, which is a good ratio. Besides, the woman's image at the social level is in the second rank with a relative weight of $70.34 \%$, which is a good ration too. The third rank is 
occupied by the woman's image at the cultural level with a relative weight of $68.92 \%$, which is a fair one, while the fourth rank is occupied by the woman's image at the economic level with a relative weight of $63.35 \%$, which is a fair one as well. Eventually, the total degree of the scale has a relative weight of $68.89 \%$, which is a fair one too. Accordingly, the researchers of this study attribute these outcomes to the woman's great interests at the political level and her salient role basically in this field, followed by her social role, the cultural role, and finally the economic role which occupies the fourth rank due to the general Palestinian economic status quo.

Table 3. The frequencies, means, standard deviations, and relative weight for each domain of the scale domains and their order

\begin{tabular}{cccccc}
\hline Domain & Sum of Responses & Mean & SD & RW & Order \\
\hline Woman's Image at the Social Level & 10439 & 19.696 & 2.670 & 70.34 & 2 \\
Woman's Image at the Political Level & 9127 & 17.221 & 2.956 & 71.75 & 1 \\
Woman's Image at the Cultural Level & 11689 & 22.055 & 3.308 & 68.92 & 3 \\
Woman's Image at the Economic Level & 6715 & 12.670 & 3.579 & 63.35 & 4 \\
Total & 37970 & 71.642 & 7.851 & 68.89 & \\
\hline
\end{tabular}

SD, standard deviation; RW, relative weight

\subsection{The answer of the third question of the study}

Table 4 represents the question, which is "what is the Palestinian woman's image like at the social level in media from the Palestinian university female students' perspective in Gaza?”. The arithmetic means and standard deviations of the individuals' responses of the study sample have been calculated.

It shows that the two highest items of the field are item 7 which occupies the first rank with a relative weight of $87.12 \%$ and item 5 which occupies the second rank with a relative weight of $80.75 \%$. On the other hand, the lowest items of the domain are item 4 which occupies the sixth rank with a relative weight of $63.35 \%$ and item 3 which occupies the last rank with a relative weight of $56.70 \%$. The entire degree of the domain is of a relative weight of $70.34 \%$. 


\section{Macrothink}

Table 4. The frequencies, means, standard deviations, and relative weight for each item of the first domain (woman's image at the social level) and its order

\begin{tabular}{|c|c|c|c|c|c|}
\hline No. & Item & Mean & SD & RW & Order \\
\hline 1 & $\begin{array}{l}\text { Do you agree that commercials have helped deface the } \\
\text { Palestinian woman's image? }\end{array}$ & 2.551 & 0.932 & 63.77 & 5 \\
\hline 2 & $\begin{array}{l}\text { Does media cast light on the Palestinian woman's } \\
\text { issues and her suffering? }\end{array}$ & 3.055 & 0.829 & 76.37 & 3 \\
\hline 3 & $\begin{array}{l}\text { Does media exaggerate in typifying the Palestinian } \\
\text { woman's image in the issues of violence which she } \\
\text { may practice or which may be practiced against her? }\end{array}$ & 2.268 & 1.043 & 56.70 & 7 \\
\hline 4 & $\begin{array}{l}\text { Does advertisements concentrate on presenting the } \\
\text { Palestinian woman as a housewife having nothing to } \\
\text { do but housekeeping and cooking? }\end{array}$ & 2.534 & 1.120 & 63.35 & 6 \\
\hline 5 & $\begin{array}{l}\text { Does most of the advertisements the Palestinian } \\
\text { woman as an effective partner of family and } \\
\text { community? }\end{array}$ & 3.230 & 0.876 & 80.75 & 2 \\
\hline 6 & $\begin{array}{l}\text { Does media portray the Palestinian woman as a } \\
\text { woman without an independent identity (in this case, } \\
\text { she is either a daughter, wife or a sister of someone?) }\end{array}$ & 2.574 & 1.192 & 64.34 & 4 \\
\hline 7 & $\begin{array}{l}\text { Do you think that social media is one of the fastest } \\
\text { contemporary means helping shape the mainstream } \\
\text { pro the Palestinian woman's social issues? }\end{array}$ & 3.574 & 0.846 & 87.12 & 1 \\
\hline & Total Degree of Domain & 19.696 & 2.670 & 70.34 & \\
\hline
\end{tabular}

$\mathrm{SD}$, standard deviation; RW, relative weight

\subsection{The answer of the fourth question of the study}

Table 5 represents the question, which is "what is the Palestinian woman's image like at the political level in media from the Palestinian university female students' perspective in Gaza?”. The arithmetic means and standard deviations of the individuals' responses of the study sample have been calculated.

It shows that the two highest items of the domain are item 1, which occupies the first rank with a relative weight of $84.86 \%$ and item 3 which occupies the second rank with a relative weight of $80.33 \%$. On the contrary, the two lowest items of the domain are item 5 which occupies the fifth rank with a relative weight of 59.53\%, and item 4 which occupies the last 
rank with a relative weight of $59.10 \%$. The total degree of the domain is of relative weight of $71.75 \%$.

Table 5. The frequencies, means, standard deviations, and relative weight for each item of the second domain (woman's image at the political level) and its order

\begin{tabular}{|c|c|c|c|c|c|}
\hline No. & Item & Mean & SD & RW & Order \\
\hline 1 & $\begin{array}{l}\text { Have some prominent Palestinian media ladies with } \\
\text { significant roles grabbed your attention while covering } \\
\text { the Palestinian political news? }\end{array}$ & 3.394 & 0.941 & 84.86 & 1 \\
\hline 2 & $\begin{array}{l}\text { While watching media, have some Arab media ladies } \\
\text { with significant roles drawn your attention while } \\
\text { covering the hot incidents in Palestine? }\end{array}$ & 3.168 & 1.040 & 79.20 & 3 \\
\hline 3 & $\begin{array}{l}\text { Has the Palestinian media man outclassed the } \\
\text { Palestinian media lady in covering the hot issues? }\end{array}$ & 3.213 & 0.992 & 80.33 & 2 \\
\hline 4 & $\begin{array}{l}\text { Has media contributed in supporting the Palestinian } \\
\text { woman for empowering her to occupy the } \\
\text { high-ranking ministerial and governmental positions? }\end{array}$ & 2.364 & 1.066 & 59.10 & 6 \\
\hline 5 & $\begin{array}{l}\text { Has media shed light on the Palestinian woman's } \\
\text { participation in the political parties? }\end{array}$ & 2.381 & 1.035 & 59.53 & 5 \\
\hline 6 & $\begin{array}{l}\text { Is social media trustworthy sources for recognizing the } \\
\text { most important political issues about the Palestinian } \\
\text { woman? }\end{array}$ & 2.700 & 1.041 & 67.50 & 4 \\
\hline & Total Degree of Domain & 17.221 & 2.956 & 71.75 & \\
\hline
\end{tabular}

SD, standard deviation; RW, relative weight

\subsection{The answer of the fifth question of the study}

Table 6 represents the question, which is "what is the Palestinian woman's image like at the cultural level in media from the Palestinian university female students' perspective in Gaza?”. The arithmetic means and standard deviations of the individuals' responses of the study sample have been calculated.

It shows that the two highest items of the domain are item 2, which occupies the first rank with a relative weight of $87.55 \%$, and item 4 which occupies the second rank with a relative weight of $82.17 \%$. On the other hand, the two lowest items of the domain are 6 which occupies the seventh rank with a relative weight of 53.44\%, and item 8 which occupies the 
last rank with a relative weight of $43.40 \%$. Finally, the total degree of the domain is of a relative weight of $68.92 \%$.

Table 6. The frequencies, means, standard deviations, and relative weight for each item of the third domain (woman's image at the cultural level) and its order

\begin{tabular}{|c|c|c|c|c|c|}
\hline No. & Item & Mean & SD & RW & Order \\
\hline 1 & $\begin{array}{l}\text { Does the Palestinian media focus on the Palestinian } \\
\text { woman's success stories? }\end{array}$ & 3.249 & 0.786 & 81.23 & 3 \\
\hline 2 & $\begin{array}{l}\text { Have traditions and customs helped keep media from } \\
\text { adopting important issues treating the Palestinian } \\
\text { woman's social and political status quo? }\end{array}$ & 3.502 & 0.792 & 87.55 & 1 \\
\hline 3 & $\begin{array}{l}\text { Has social media reflected key and vital issues about } \\
\text { the Palestinian woman? }\end{array}$ & 3.134 & 0.854 & 78.35 & 4 \\
\hline 4 & $\begin{array}{l}\text { Do you think that presenting exemplars of the } \\
\text { Palestinian woman's constructive participation on } \\
\text { social media helps change the stereotype about the } \\
\text { Palestinian woman? }\end{array}$ & 3.287 & 0.891 & 82.17 & 2 \\
\hline 5 & $\begin{array}{l}\text { Do advertisements foment the Palestinian woman's } \\
\text { dissatisfaction with the status quo? }\end{array}$ & 2.525 & 0.982 & 63.11 & 5 \\
\hline 6 & $\begin{array}{l}\text { Does media present the Palestinian woman as a } \\
\text { woman lacking the mental abilities for thoughts and } \\
\text { sentiments? }\end{array}$ & 2.138 & 1.113 & 53.44 & 7 \\
\hline 7 & $\begin{array}{l}\text { Does media depict the Palestinian woman as a } \\
\text { passionate woman incapable to make decisions? }\end{array}$ & 2.485 & 1.157 & 62.12 & 6 \\
\hline 8 & $\begin{array}{l}\text { Does media characterize the successful Palestinian } \\
\text { woman as an unsuccessful wife or mother? }\end{array}$ & 1.736 & 1.017 & 43.40 & 8 \\
\hline & Total Degree of Domain & 22.055 & 3.308 & 68.92 & \\
\hline
\end{tabular}

SD, standard deviation; RW, relative weight

\subsection{The answer of the sixth question of the study}

Table 7 represents the question, which is "what is the Palestinian woman's image like at the economic level in media from the Palestinian university female students' perspective in Gaza?". The arithmetic means and standard deviations of the individuals' responses of the study sample have been calculated. 
It shows that the highest item of the domain is item 5 which occupies the first rank with a relative weight of $67.59 \%$. On the other hand, the lowest item of the domain is item 1 which occupies the last rank with a relative weight of 53.02\%. The total degree of the domain is of a relative weight of $63.35 \%$.

Table 7. The frequencies, means, standard deviations, and relative weight for each item of the fourth domain (woman's image at the economic level) and its order

\begin{tabular}{|c|c|c|c|c|c|}
\hline No. & Item & Mean & SD & RW & Order \\
\hline 1 & $\begin{array}{l}\text { Does media present the Palestinian woman as a } \\
\text { commodity in drama and commercials? }\end{array}$ & 2.121 & 1.132 & 53.02 & 5 \\
\hline 2 & $\begin{array}{l}\text { Does media portray the Palestinian woman as a } \\
\text { woman playing a marginal or secondary role less } \\
\text { important than the man's one in the process of the } \\
\text { social development? }\end{array}$ & 2.557 & 1.109 & 63.92 & 4 \\
\hline 3 & $\begin{array}{l}\text { Does media present the Palestinian woman as a } \\
\text { woman unable to run economic projects? }\end{array}$ & 2.619 & 1.030 & 65.47 & 3 \\
\hline 4 & $\begin{array}{l}\text { Does media depict the Palestinian woman as a woman } \\
\text { financially depending on man and unable to support } \\
\text { her life? }\end{array}$ & 2.670 & 1.192 & 66.75 & 2 \\
\hline 5 & $\begin{array}{l}\text { Does media unveil examples of the Palestinian } \\
\text { working woman's materialistic abuse? }\end{array}$ & 2.704 & 1.044 & 67.59 & 1 \\
\hline & Total Degree of Domain & 12.670 & 3.579 & 63.35 & \\
\hline
\end{tabular}

SD, standard deviation; RW, relative weight

After considering the outcomes, the researchers of this study have found that these outcomes represent the reality. To explain more, the contemporary inventions like the social media networks have greatly helped shape the Palestinian woman's image. Despite the Palestinian woman's effective participation and designation in significant positions, the customs, traditions, difficult political and economic circumstances have diminished the Palestinian woman's role to some extent. However, there are some Palestinian women who engineered a history for themselves and left a fingerprint history recorded, like Poetess Fadwa Toqan, and Miss Hanan Hroub who was awarded the Noble Prize for the best teacher of the world. 


\section{Recommendations}

1. Having media not to exaggerate in depicting the woman's image in the issues of violence, seeking to have a positive image about her and defending her freedom and rights.

2. Providing the media support needed to help women occupy governmental and ministerial positions and reinforcing her role once in leadership positions.

3. Highlighting some exemplars for successful women who are of mental distinct abilities in the field of reasoning and knowledge, and revealing the women who have made literary and scientific products.

4. Setting a media plan based on justice and equality in expressing what both of man and woman achieve in the societal development, and showing the strengths for leverage for women.

\section{Limitations of the Study}

This study has been confined to a sample of female students of the Islamic University of Gaza, Al-Azhar University, and University of Palestine. These students are enrolled in the first semester of the scholastic year of 2015-2016.

\section{Acknowledgment}

The authors extend sincere thanks to the participants for their willingness to participate in this study, and to Islamic university, Al-Azhar University, and University of Palestine for field work permission.

\section{Conflict of Interest}

The authors declare that they have no significant competing financial, professional or personal interests that may influence the performance or presentation of the work described in this manuscript.

\section{References}

Abu-Taha, H. (2013). The Effect of the Social Media on Handling the Woman's Social Issues from Media Persons' Perspective in the Gaza Strip. The Center of the Woman's Issues: Gaza. [Arabic]

Albayadi, A. K., \& Somaisem, H. (2013). The Role of Palestinian Media in Supporting the Rights of Palestinian Refugee Woman from the Point of View of Female Students of Media Collage in the Gaza Strip. Middle East University. Jordan. Master Thesis. Retrieved from: http://goo.gl/neBuKC. [Arabic]

Al-Dahdouh, A. (2010). The Woman's Image in the Advertisements of the Arab TV Channels for the Female Students of the Islamic University. (Unpublished master dissertation). The Islamic University of Gaza. Palestine. [Arabic] 
Al-Damiri, E. (2002). The Woman's Reality in the Jordanian Daily Journalism: an Analytical Study on the Newspapers of Al-Aswaq, Al- Arab Al-Yawm, Al- Dustur and Al-Ra'ay. AL-Quds Center for Political Studies. Retrieved from: http://goo.gl/XeT5tV. [Arabic]

Al-Manshi, M. (2011). The Woman's Rights between the International Charters and the Genuineness of the Islamic Sharia. First Edition. Dar Al-Thaqafa for Publishing and Distribution. Amman. Jordan. [Arabic]

Al-Salem, Z. (1997). The Arab Woman's Image in the Televised Drama, the Home of Aram for Studies and Publishing. Amman. Jordan. [Arabic]

Al-Zubedi, S. (2005). The Role of the Feminist Associations in Changing the Woman's Image in Media, Paper from the Files of Wednesday's Dialogue, the File of Women and Media, Kana'an Developmental and Educational Institute, a series of dialogues (11). Gaza. Palestine. [Arabic]

An-Nahr, N., Sowdani, H., \& Hatem, L. (2008). The Woman's Image in the Arab Media: An Analytical Study for Handling the Woman's Image in the Channel of mbc 1 as an example. Master Thesis. The Arab Academy in Denmark. Retrieved from: http://goo.gl/7JMY4e. [Arabic]

Arab Woman's Organization (2008). The Arab Woman's Media Strategy 2009-2015. The Arab Woman's Organization. Retrieved from: http://goo.gl/JIEA1W. [Arabic]

Bader, M., \& Al-Mousa, I. (2009). The Image of the Jordanian Woman in Daily Jordanian Newspapers. Middle East University. Jordan. Master dissertation. Retrieved from: http://goo.gl/LSizjZ. [Arabic]

Ghattas, F., \& Sawadeh, N. (2011). Observing the Woman's Image in the Month of September in the Three Palestinian Newspapers of AL-Quds, AL-Ayam, and Al-Haya Al-Jadedah. The Arab Network for Changing the Man and Woman's Image in Media. PP: 87-131. Palestine. Retrieved from: http://goo.gl/URwNMy. [Arabic]

Hazayma, O. (2006). Arabization and the Linguistic Security, the Magazine of Arabization. Arab Center for Arabization. Damascus. [Arabic]

Kamel, N. (2006). Media and Woman in City and Suburb: An Applied Study on Egypt and Bahrain. Retrieved from: http://goo.gl/UQSRxW. [Arabic]

Ramzy, N. (2001). Women and Media in a Changing World. The Lebanese Egyptian Home: Cairo. [Arabic]

Shimon, H. (2008). The Palestinian Media Lady's' Reality of Profession. The Woman's Affairs Center. Gaza. Palestine. [Arabic]

Shimon, H. (2010). Media is our Window towards the World, the Woman's Image in the Palestinian Media, the Gaza Strip- Special Study. The Woman's Affairs Center. Gaza. Palestine. 


\section{Macrothink}

Yusuf, R. (2005). The Woman's Image in the Religious Journalism: An Analytical Study for the newspapers of Al-Lewaa Al-Eslami, Aqedati, and Al-Azhar. The Woman's Image in Media. Center of the Family Studies. Cairo PP. 91-155. [Arabic]

\section{Copyright Disclaimer}

Copyright for this article is retained by the author(s), with first publication rights granted to the journal.

This is an open-access article distributed under the terms and conditions of the Creative Commons Attribution license (http://creativecommons.org/licenses/by/3.0/). 